\title{
Pain Management in Patients with Peripheral Arterial Disease
}

\author{
Buket Ozyaprak $^{1 *}$, Nail Kahraman ${ }^{2}$, Kurtbey Anarat ${ }^{1}$, Mehmet Gaml1 ${ }^{1}$, Gönül Erkan ${ }^{3}$, Ahmet Eroğlu ${ }^{4}$ \\ ${ }^{1}$ Department of Anesthesiology and Reanimation, Bursa Yüksek Ihtisas Training and Research Hospital, Health \\ Sciences University, Y1ldırım/Bursa, Turkey \\ ${ }^{2}$ Department of Cardiovasculary Surgery, Bursa Yüksek Ihtisas Training and Research Hospital, Health Sciences \\ University, Turkey. \\ ${ }^{3}$ Department of Anesthesiology and Reanimation, Ahi Evren Training and Research Hospital, Health Sciences \\ University, Trabzon, Turkey, \\ ${ }^{4}$ Department of Anesthesiology and Reanimation, Karadeniz Technical University, Trabzon, Turkey, \\ e-mail: ozyaprakertugrul@gmail.com,nailkahraman1979@yahoo.com,kurtbey_anarat@hotmail.com, \\ mehmetgamli@gmail.com, aheroglu@hotmail.com \\ Orcid: 0000-0002-6327-4573 \\ Orcid: 0000-0001-9343-0947 \\ Orcid: 0000-0003-2319-0145 \\ Orcid: 0000-0002-5618-2734 \\ Orcid: 0000-0002-2028-4288 \\ Orcid: 0000-0002-0396-1582 \\ * Corresponding Author: Sorumlu Yazar: Buket Ozyaprak
}

Gönderim Tarihi / Received: 20.11.2019

Kabul Tarihi / Accepted: 17.01.2020

DOI: $10.34087 /$ cbusbed.648815

\begin{abstract}
Amaç: Periferik arter hastalığı ateroskleroz zemininde oluşan ve sıklığı giderek artan kronik bir hastalıktır. Periferik arter hastalığında Fontaine ve Rutherford sınıflaması sık kullanılan evrelendirme yöntemlerindendir. İskemi ile oluşan istirahat ağrısı (Fontaine 3-4) hasta hayatını olumsuz etkilemektedir ve tedavisi hastalığın tedavisi kadar önemli olmaktadır. Ağrıyı doğru değerlendirme de bu konuda doğru yaklaşımı sağlamaktadır. Visüel Anolog Skalası ve sözel tarif skalası ağrı ölçümünde kullanılan skalalardandır. Biz de hastanemizde periferik arter hastalığı nedeni ile ağrı tedavisi verdiğimiz hastalarımızı değerlendirerek sonuçları ile literatüre katkıda bulunmayı amaçlıyoruz.

Materyal Metod: Ocak 2014 ve Eylül 2018 tarihleri arasındaki periferik arter hastalığı nedeni ile ağrı tedavisi verdiğimiz hastalar retrospektif çalı̧̧ma yöntemi ile araştırıldı. İskemiye bağlı istirahat ağrısı olan Fontaine evre 3-4 hastalar çalışmaya dahil edilirken, ağrısı olmayan Fontaine evre 1-2 hastalar çalıșma dıșı bırakıldı. Ağrı seviyesini değerlendirmek için sözel tanımlayıcı ağrı ölçeği kullanıldı. Araştırma hasta dosyalarından ve hastane bilgi işlem sisteminden yapıldı.

Bulgular: Periferik arter hastalığı nedeniyle ağrı tedavisi verilen 7 kadın, 8 erkek toplam 15 hastanın yaş ortalaması $69.13 \pm 8.11$ olarak saptandı. Fontaine sinıflamasına göre evre 3 'ten 6 hasta, evre 4 'ten 9 hasta belirlendi. Sözel tarif skalasına göre; hafif şiddette ağrısı olan 5 hasta, orta şiddette ağrısı olan 7 hasta, ciddi şiddette ağrısı olan 3 hasta tespit edildi. Ağrı tedavisi için 1 hastaya epidural kateter ile hasta kontrollu analjezi uygulanırken 14 hastaya farmokolojik tedavi ugulandığı belirlendi.

Sonuç: Periferik arter hastalığı ağrı tedavisinde doğru tedavi için doğru değerlendirme önemlidir. Bu konuda hasta ile kurulacak iletişim önemlidir. Ağrı için verilecek tedavide de oluşabilecek riskler ekiplerin işbirliği ile multidisipliner bir yaklaşımla yapılmalıdır.
\end{abstract}

Anahtar Kelimeler: Periferik arter hastalığı, ağrı, sözel tarif skalası, Fontaine evrelemesi

\footnotetext{
Abstract

Aim: A chronic disease with increasing frequency, peripheral arterial disease occurs due to atherosclerosis. Fontaine and Rutherford classifications are common staging methods in peripheral arterial disease. Resting pain caused by
} 
ischemia (Fontaine 3-4) adversely affect the patient's life and their treatment is as important as the treatment of the disease. Accurate assessment of pain also provides the right approach. The Visual Analogue Scale and verbal descriptive pain scale are among the various scales used in pain measurement. We aim to contribute to the literature by evaluating our patients who were treated with pain due to peripheral arterial disease in our hospital.

Materials and Methods: Patients with peripheral arterial disease who were treated for pain between January 2014 and September 2018 were investigated retrospectively. Those with resting pain due to ischemia (Fontaine stage 3-4) were included in the study, while Fontaine stage 1-2 patients without pain were excluded. Verbal descriptive pain scale was used to assess the pain level. The data were obtained from the patient files and hospital registry.

Results: The mean age of the 15 patients who had pain treatment for peripheral arterial disease was $69.13 \pm 8.11$ years. The patients included 7 females and 8 males. Six stage 3 and nine stage 4 patients were identified based on Fontaine classification. According to the verbal descriptive pain scale, 5 had mild, 7 had moderate and 3 had severe pain. One patient underwent epidural catheter placement for administration of patient-controlled analgesia while 14 patients received pharmacological treatment.

Conclusion: Accurate assessment is important for appropriate pain treatment in peripheral arterial disease. Communication with the patient is important in this regard. Risks that may occur in the treatment of pain should be undertaken with a multidisciplinary approach.

Keywords: Peripheral arterial disease, pain, verbal descriptive pain scale, Fontaine classification

\section{Introduction}

A cause of mortality and morbidity, peripheral arterial disease (PAD) is an increasingly important health problem that significantly affects quality of life. PAD, which is generally used for lower extremity circulation, also includes extracranial carotid, upper extremity, visceral and renal circulation $[1,2]$. The most common cause is atherosclerosis, explaining the high incidence of cardiovascular diseases in PAD patients. This increases mortality and morbidity $[1,2]$.

The clinical manifestations of peripheral arterial disease are caused by narrowing and occlusion of the arterial system. Initial walking pain (intermittent claudication) progresses to pain occurring during rest [3-5]. Other symptoms due to ischemia following arterial obstruction are discoloration and numbness, while the most serious symptom is ulceration and gangrene in the affected extremity (Figure 1, Figure 2).

Ankle / brachial pressure index (ABI) measurement is commonly used in physical examination in PAD [3-5]. In this method, systolic pressure ratio of the ankle to the brachium is measured and any result that is less than 0.9 is in favor of PAD (3-5). When appropriate and timely treatment is not administered, patients may face dire consequences, such as amputation of the affected limb [6].

Fontaine and Rutherford classifications are commonly used in clinical staging of PAD [5]. Fontaine staging is as follows: Stage 1: asymptomatic, Stage 2-A: mild claudication, Stage 2-B: moderate-severe claudication, Stage 3: resting pain, Stage 4: ulceration and gangrene. In the Rutherford classification system, category 0 includes asymptomatic patients, category 1 includes those with mild claudication, category 2 , those with moderate claudication, category 3 , severe claudication, category 4 , resting pain, category 5 , minor tissue loss and category 6 , patients with major tissue loss.

Treatment of peripheral arterial disease comprises lifestyle changes such as weight loss, exercise and smoking cessation along with thetreatment of atherosclerotic risk factors such as hypertension, hyperlipidemia and diabetes [4,7].

The interventional and surgical treatment options for arterial obstruction include administration of thrombolytic therapy via a percutaneous catheter, adjuvant surgical embolectomy, thrombus aspiration, endovascular therapies, and aorta-bifemoral, aortaunifemoral, aorta-iliac, iliofemoral, axillo-femoral, femoro-popliteal bypass [7]. Pharmacologically, antithrombotic agents, pentoxifylline, cilastazole and iloprost may be administered [8]. Pain control should be effectively achieved in these patients, whose qualities of life are severely affected.

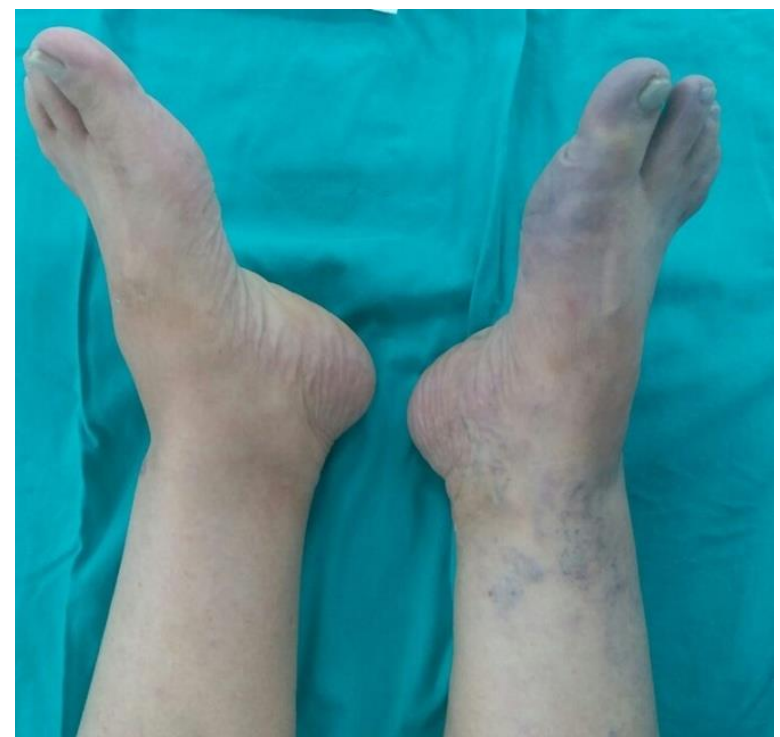

Figure 1: Ischemia of the Extremity 


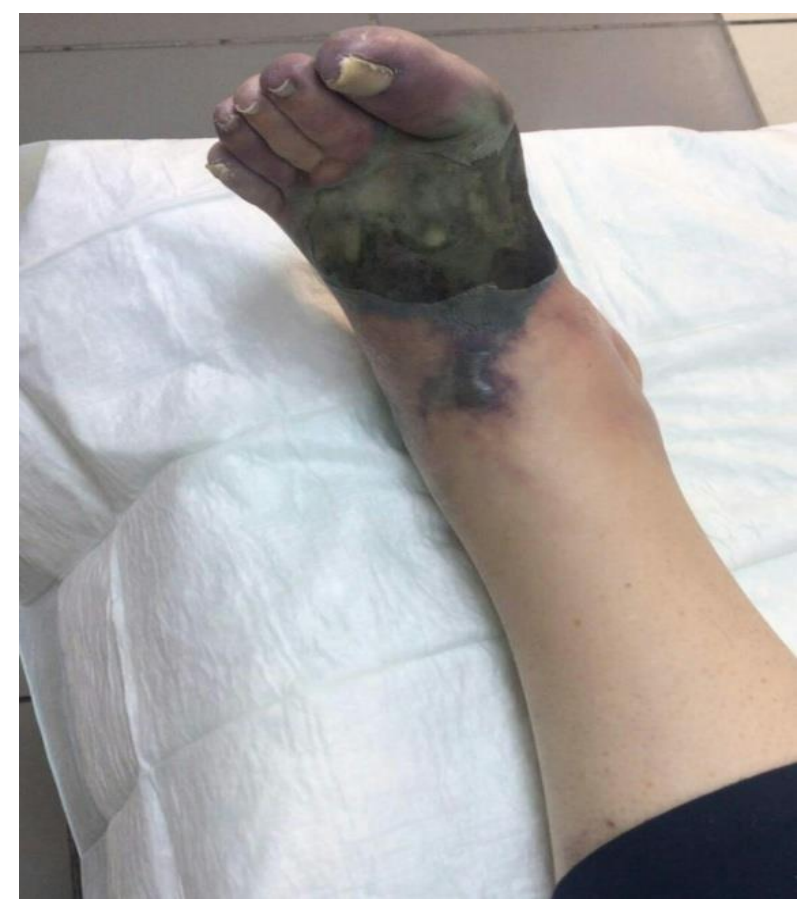

Figure 2: Ulcer and gangrene in the extremity

We aim to contribute to the literature by investigating the treatments and outcomes we administered to patients with ischemic extremity pain at rest due to PAD in our clinic.

\section{Materials and Methods}

This study was conducted retrospectively on patients who were treated with the diagnosis of PAD in our hospital between January 2014 and September 2018. Approval was obtained from the Ethics Committee in accordance with the Helsinki Declaration. Demographic data, physical examination and laboratory findings, imaging methods results, and treatments were analyzed from the patient files and hospital registry. PAD stages were evaluated with the Fontaine staging system. Fontaine stage 3 and stage 4 patients who were hospitalized for treatment of PAD and ischemic extremity pain were included in the study while Fontaine stage 1 and stage 2 patients without ischemic extremity pain were excluded.

\subsection{Routine Surgical Procedure}

Detailed physical examinations of the patients who were hospitalized with the diagnosis of PAD were performed after questioning their medical and disease-related history. ABI was measured and distance of claudicatio intermittens was noted. Routine blood tests, electrocardiography and echocardiography were performed. In physical examination, paleness, coldness, cyanosis in the extremities, failure to palpate peripheral pulses manually and/or with a hand doppler and $\mathrm{ABI}<0.9$ were considered consistent with ischemic PAD. Vascular imaging was performed by ultrasonography, computerized tomographic angiography, or conventional angiography. Medical or surgical treatment options were chosen according to the clinical signs and symptoms of the patients. Anesthesia consultation was arranged for pre-evaluation of surgical patients and pain control. Patients in which amputation could not be avoided despite vascular surgery and pharmacological treatment were transferred to the Orthopedics and Traumatology Department.

\subsection{Routine Pain Treatment Procedure}

Before the treatment of patients with extremity pain due to PAD, the type (whether it was neuropathic pain) and severity of pain was determined by physical examination. Verbal descriptive pain scale was used to assess the pain level. According to this scale, the patients' pain was classified into four groups: No pain, mild, moderate, and severe pain. Step-"ladder" approach was used to determine the appropriate treatment according to the severity of pain. Pharmacological agents were administered first, followed by epidural catheter placement in patients without any contraindications if necessary. For patients suffering from mild and moderate pain, nonsteroidal anti-inflammatory drugs (tenoxicam), acetaminophen, mild opioids (tramadol), or a combination of these were administered, while oral, subcutaneous, intravenous or transdermal use of a potent opioid such as pethidine and fentanyl was recommended for patients with severe pain. Patient-controlled analgesia pump was used as interventional pain treatment in consenting patients with no contraindications, which included impaired coagulation tests, failed cessation of thrombolytic or anticoagulant treatments, local infection at the site of intervention, vertebral colon deformities, arthritis, history of laminectomy or trauma in the lumbar region and presence of neurological disease. In patients with neuropathic pain, antidepressants combined with either gabapentin or pregabalin were administered in accordance with the recommendations made by the consultant neurologist.

\subsection{Statistical method}

SPSS 21.0 (Statistic Inc. version Chicago, IL, USA) software was used for the statistical analysis of the data. Descriptive statistics were expressed as mean \pm standard deviation for continuous variables, and as number of patients (\%) for nominal variables. At $95 \%$ confidence interval, $\mathrm{p}<0.05$ was considered statistically significant.

\section{Results:}

Among 82 patients whose data were obtained from the hospital registry and patient files, 15 patients in Fontaine 3rd and 4th stages with extremity pain during resting were included in the study. 67 Fontaine stage 1 and stage 2 patients without resting ischemic limb pain were excluded from the study. The mean age of the 15 patients treated for pain due to PAD ( 7 females, 8 males) was $69.13 \pm 8.11$ years (Table 1$)$. Demographic data and comorbid factors of our patients are summarized in Table 1. 
Table 1: Demographic Data and Comorbidities

\begin{tabular}{|l|c|c|}
\hline \multicolumn{2}{|c|}{$\begin{array}{c}\text { Number } \\
\text { of patients } \\
\text { (n) }\end{array}$} & $\begin{array}{c}\text { Percen } \\
\text { tage } \\
(\%)\end{array}$ \\
\hline Females & 7 & 46.7 \\
\hline Males & 8 & 53.3 \\
\hline Smoking & 11 & 73.3 \\
\hline $\begin{array}{l}\text { Chronic Obstructive Pulmonary } \\
\text { Disease }\end{array}$ & 9 & 60 \\
\hline Diabetes Mellitus & 8 & 53.3 \\
\hline Hypertension & 13 & 86.7 \\
\hline Coronary Artery Disease & 7 & 46.7 \\
\hline Cerebrovascular Disease & 1 & 6.7 \\
\hline Morbid Obesity & 1 & 6.7 \\
\hline \hline Mean age (Years) \pm SD & $69.13 \pm 8.11$ & \\
\hline SD: Standard Deviation & & \\
\hline
\end{tabular}

Six patients were in Fontaine Stage 3 and 9 were in stage 4. The distribution of patients according to the severity of pain are presented in Table 2.

Table 2: Distribution of Patients According to The Severity of Pain

\begin{tabular}{|l|c|c|}
\hline \multicolumn{2}{|c|}{$\begin{array}{c}\text { Number of } \\
\text { patients (n) }\end{array}$} & $\begin{array}{c}\text { Percentage } \\
(\%)\end{array}$ \\
\hline Mild pain & 5 & 33.3 \\
\hline Moderate pain & 7 & 46.7 \\
\hline Severe pain & 3 & 20 \\
\hline
\end{tabular}

Pharmacological treatment of PAD pain included paracetamol (acetaminophen), tenoxicam as a nonsteroid anti-inflammatory agent, tramadol as a mild opiate, and pethidine and fentanyl as potent opioids (Table 3). All these agents were administered intravenously except for fentanyl, for which transdermal administration was preferred. Patient-controlled analgesia with epidural catheter placement was performed to one patient (Table 3). Two patients were treated for neuropathic pain.

We determined that all patients were treated with antithrombotic (anticoagulant or antiplatelet) agents for PAD, and in one patient who underwent epidural catheter placement, the treatment was switched to low molecular weight heparin and stopped 12 hours before the procedure. Iloprost was ordered for all patients, and intravenous antithrombotic treatment was administered to 11 patients. Including the unresponsive patients to pharmacological therapy, a total of 6 patients underwent embolectomy and 5 underwent bypass surgery. Four
Table 3: Distribution of pain treatment of patients

\begin{tabular}{|l|c|c|}
\hline & $\begin{array}{l}\text { Number of } \\
\text { patients (n) }\end{array}$ & $\begin{array}{l}\text { Percentage } \\
(\boldsymbol{\%})\end{array}$ \\
\hline NSAI drugs & 2 & 13.3 \\
\hline Tramadol (Mild Opioid) & 3 & 20 \\
\hline Tramadol -Paracetamol & 4 & 26.7 \\
\hline Pethidine (Potent Opioid) & 3 & 20 \\
\hline Fentanyl (Potent Opioid) & 2 & 13.3 \\
\hline PCA with Epidural Catheter & 1 & 6.7 \\
\hline
\end{tabular}

NSAI: Nonsteroid anti-inflammatory, PCA: Patient-controlled analgesia

patients had redo surgeries while despite all efforts, 5 patients were transferred to the Orthopedics and Traumatology Department for amputation. Complications included postoperative bleeding in one patient and superficial wound infection in two patients.

\section{Discussion:}

Pain has caused great convalescence throughout history, and pain treatment has been a principal factor contributing to the holy position of medicine. The International Pain Research Association has described it as "an unpleasant, sensory and emotional experience that accompanies or can be identified with possible or existing tissue damage" [9].

Pain alters the quality of life due to its negative effects on physical activity, social life, and sleep [10]. However, pain also causes sympathetic activation in the body [11], which is why pain treatment should accompany the treatment of the disease itself.

While PAD develops at the basis of atherosclerosis, it is associated with various risk factors such as diabetes mellitus, hypertension, coronary artery disease, cerebrovascular disease, and smoking [4,5]. Sympathetic activation caused by pain increases blood glucose levels and blood pressure, aggravating these comorbidities and heightening the risk. All the above-mentioned factors make pain management particularly important for PAD. In our patient group, these comorbidities existed in consistence with the literature (Table 1).

It is necessary to evaluate the patient's pain correctly to administer the appropriate treatment. Various methods are used for pain measurement, two of the most wellknown being the visual analogue scale (VAS) and the verbal descriptive pain scale. VAS is used for measuring pain severity and follow-up [11]. The verbal description scale classifies the severity of pain into four groups: None, mild, moderate, and severe [11-13].

In our physical examination, we used the verbal descriptive pain scale to measure the severity of pain and we classified patients into mild, moderate, and severe pain groups (the group without pain according to verbal descriptive pain scale was not included in the study) (Table 2).

Although pharmacological and interventional methods are both used in the treatment of pain, pharmacological 
methods are at the forefront. The World Health Organization (WHO) recommends step"ladder"approach according to the type (neuropathic or neuroceptive) and severity of pain [14,15]. In mild and moderate pain, NSAIDs or weak opioids in combination with paracetamol or alone are recommended while potent opioids are the first drug of choice in severe pain. Medications recommended as adjuvant therapy in neuroleptic pain include antidepressants, calcium channel a2 delta ligands (gabapentin, pregabalin) and topical lidocaine $[14,15]$. Interventional procedures are also used in the treatment of pain [16,17]. While pharmacological methods were preferred in 14 of 15 of our patients, one patient underwent epidural catheter placement for patient-controlled analgesia (Table 3). The reason that the interventional methods were not preferred is that all our patients were receiving antithrombotic treatments for PAD. In one patient who underwent epidural catheter placement, the treatment was switched to low molecular weight heparin and stopped 12 hours before the procedure.

Antithrombotic treatments constitute a frequent problem faced by physicians performing interventional pain procedures. In the literature, $25 \%$ of these patients are reported to receive antithrombotic treatment [16]. This rate reached $100 \%$ in our PAD patients, well above this figure.

Interventional pain procedures and the use of antithrombotic drugs have been frequently discussed. The continuity of antithrombotic therapy prevents thromboembolic events such as cardiovascular, cerebrovascular, and peripheral arterial diseases, which are important causes of mortality and morbidity. However, this treatment brings forth its own complications such as bleeding, especially during the interventional procedure [16]. Current literature suggests that cessation of antithrombotic therapy increases thromboembolic events rather than reducing hemorrhagic complications [16,18]. This emphasizes pharmacological therapy and the step- "ladder" treatment approach proposed by $\mathrm{WHO}$, as in our patients.

There are studies in the literature comparing pharmacological treatment procedures in managing postoperative pain. Cattabriga et al. stated that the ideal pain treatment should be easy to administer, provide sufficient analgesia and reduce the total amount of opioid to be used [9]. They also reported that the use of intravenous paracetamol for postoperative pain after cardiac surgery reduced morphine consumption [9]. A similar study was performed by Aubrun et al. [19], who investigated the effect of paracetamol on morphine consumption after disc surgery and found that paracetamol use reduced morphine consumption by $18 \%$ in patients with severe pain and $37 \%$ in patients with moderate pain. Studies investigating the side effects of morphine have also been conducted. Remy et al. found that the concurrent use of morphine and paracetamol did not change the incidence of morphine-related side effects during the postoperative period [20].
New treatment modalities for pain in PAD have been investigated. In their study on patients with critical leg ischemia, Yonemitsu et al. found that gene therapy administered with viral vectors containing fibroblast growth factors increased walking distance and decreased pain [21]. However, Belch et al. reported that intramuscular injection of fibroblast growth factor was not effective on amputation-free survival [22].

This study, in which we present our clinical experience, has some limitations: The number of patients was small, and the study was conducted retrospectively. Also, there was no comparison between pain treatment methods. We believe that further prospective studies comparing different pain management methods in PAD patients are needed.

\section{Conclusion:}

Pain management in PAD should include a multidisciplinary approach, considering concurrent treatments and risks. Along with sufficient knowledge and experience of the team, effective communication with the patient is of foremost importance in comprehensive pain treatment.

\section{References:}

1. Hirsch AT, Crigui MH, et al, Peripheral arterial disease detection, awareness and treatment in primary care. Journal of American Medical Association, 2001, 286 (11),1317-24.

2. Fried RE. Diagnosis and treatment of peripheral arterial disease Journal of American Medical Association, 2002, 287 (3), 315-6.

3. Stoffers HE, Rinkers PE, et al, The prevalence of asymptomatic and unrecognized peripheral arterial occlusive disease. International Journal of Epidemiology, 1996, 25 (2), 282-290.

4. Karabay Ö, Karaçelik M, et al. İskemik periferik arter hastalığı: Bir tarama çalışması. Türk Göğüs Kalp Damar Cerrahisi Dergisi 2012, 20(3), 450-457.

5. Bozoğlan O. Diyabetes mellitus ve periferik arter hastalığı. Kahramanmaraş Sütçü İmam Üniversitesi Tıp Fakültesi Dergisi 2015, 10(2), 64-67.

6. Yakubov SJ, Bope ET. Cardiovascular disease. In: Rakel RE (ed). Textbook of family practice. 6th edition. Philadelphia: W.B. Saunders; 2002.784

7. Akdemir R, Vatan MB. 2017 Avrupa Kardiyoloji Derneği periferik arter hastalığı tanı ve tedavi klavuzunun getirdiği yenilikler. Türk Kardiyoloji Derneği Arşivi 2017, 45 (8), 681-686.

8. Mavioğlu L, Mungan U, et al, Atipik tutulum gösteren Buerger hastalığ1 (tromboanjitis obliterans): Olgu sunumu. Türk Göğüs Kalp Damar Cerrahisi Dergisi 2013, 21 (4), 1039-1042.

9. Cattabriga I, Pacini D, et al, Intravenous paracetamol as adjunctive treatment for postoperative pain after cardiac surgery: a double blind randomized controlled trial. European Journal of Cardio-thoracic Surgery 2007, 32(3), 527-531.

10. Schofield P. Pain management of older people in care homes: a pilot study. British Journal of Nursing, 2006, 15(9), 509-14.

11. Türk Anesteziyoloji ve Reanimasyon Derneği (TARD) Anestezi Uygulama Klavuzları Postoperatif Ağrı Tedavisi Mart 2006.

12. Uyar M. Postoperatif ağrılı hastanın değerlendirilmesi, ağrı ölçümü. Yücel A. Postoperatif Analjezi. Mavimer matbacılık, İstanbul 2004,27-36.

13.Eti Aslan F. Ağrı değerlendirme yöntemleri. Cumhuriyet Üniversitesi Hemşirelik Yüksekokulu Dergisi, 2002 (6), 9-16.

14. Woo KY, Abbott LK, Librach L. Evidence-based approach to manage persistent wound-related pain. Current opinion in supportive and palliative care, 2013,7 (1), 86-94.

15. Coşkun Ö, Uzun $\mathrm{G}$, et al, Kronik yarada tedavi yaklaşımları. Gülhane Tıp Dergisi, 2016, 58, 207-228

16. Takmaz SA. Girișimsel yöntemler ve antikoagülanlar. Ağrı Bülteni 2017,(2), 1-9. 
17. Caraceni A, Hanks G, et al, Use of opioid analgesics in the treatment of cancer pain: evidence-based recommendations from the EAPC The Lancet Oncology, 2012, 13 (2), 58-68.

18. Manchikanti L, Falco FJ, et al, Assesment of bleeding risk of interventional techniques: a best evidence synthesis of practice patterns and perioperative management of anticoagulant and antithrombotic therapy. Pain Physician 2013, 16 (2 Suppl), SE261318.

19. Aubrun F, Kalfon F, et al, Adjunctive analgesia with intravenous propacetamol does not reduce morphine British Journal of Anaesthesia, 2003,90(3), 314-9.

20. Remy C, Marret E, Bonnet F. Effects of acetaminophen on morphine side-effects and consuption after major surgery: metaanalysis of randomized controlled trials. British journal of Anaesthesia, 2005, 94 (4), 505-513.

21. Yonemitsu Y, Matsumoto T, et al. DVC1-0101 to treat peripheral arterial disease: A Phase I/IIa Open-label Dose escalation Clinical Trial. Moleculer therapy: The Journal of the American Society of Gene Therapy, 2013, 21 (3), 707-714.

22. Belch J, Hiatt WR, et al. Effect of fibroblast growth factor NV1FGH on amputation and death: a randomised placebo-controlled trial of gene therapy in critical limb ischemia, Lancet, 2011, 377 (9781), 1929-37.

http://edergi.cbu.edu.tr/ojs/index.php/cbusbed isimli yazarın CBU-SBED başlıklı eseri bu Creative Commons Alıntı-Gayriticari $\quad 4.0$ Uluslararası Lisansı ile lisanslanmıştır. 